\section{Host Status of Three Transgenic Plum Lines to Mesocriconema xenoplax}

\author{
Andrew P. Nyczepir ${ }^{1}$ \\ U.S. Department of Agriculture, Agricultural Research Service, Southeastern \\ Fruit and Tree Nut Research Laboratory, 21 Dunbar Road, Byron, GA 31008 \\ Alexis K. Nagel \\ Department of Genetics and Biochemistry, Clemson University, Clemson, \\ SC 29634
}

\section{Guido Schnabel \\ Department of Entomology, Soils, and Plant Sciences, Clemson University, Clemson, SC 29634}

Additional index words. Gastrodia elata, GAFP, peach tree short life, Prunus domestica, ring nematode, rootstock

\begin{abstract}
The expression of gastrodianin antifungal protein (GAFP) in a form of its VNF isoform increases tolerance to Phytophthora root rot (Phytophthora cinnamomi) and the root-knot nematode (Meloidogyne incognita) in transgenic plum lines. However, nothing is known about the potential of the GAFP lectin to confer disease resistance to the ring nematode, Mesocriconema xenoplax, in plum. Three transgenic plum lines $(4 \mathrm{I}, 4 \mathrm{~J}$, and 5D) expressing gafp-1 under the control of CaMV 35S promoter sequence were evaluated for their response to M.xenoplax in the greenhouse. All plum lines were rated as hosts of M. xenoplax. Among the individual plum lines tested, the number of M. xenoplax per gram of dry roots was lowest in the rhizosphere of transgenic line 5D, intermediate in that of the nontransformed control line, and greatest in line 4J. The results of this study indicate that the comparisons of the final soil densities (Pf) of adult and juvenile $M$. xenoplax expressed as nematodes per gram of dry roots provide a better measure of the nematode carrying capacity by the tested lines than $P f$ values referred to as number of M. xenoplax $/ 100 \mathrm{~cm}^{3}$ soil.
\end{abstract}

In the southeastern United States, the productive lifespan of peach [Prunus persica (L.) Batsch] trees does not exceed 6 to 10 years on some sites as a result of premature tree mortality (Brittain and Miller, 1978). Two causes of early tree death are a disease complex known as peach tree short life (PTSL) and Armillaria root rot (Miller, 1994; Savage and Cowart, 1942). Peach tree short life is reportedly caused by a predisposition of trees to cold injury, bacterial canker (Pseudomonas syringae pv. syringae van Hall), or a combination of both, which results from feeding by the ring nematode, Mesocriconema xenoplax (Raski, 1952) Loof \& de Grisse, 1989 [=Criconemoides xenoplax (Raski, 1952) Loof and de Grisse, 1967] (Brittain and Miller, 1978; Nyczepir et al., 1983). Mesocriconema xenoplax is an ectoparasitic nematode that has the ability to influence peach growth as a result of its feeding habit (Lownsbery et al., 1973; Nyczepir et al., 1987). In field microplots, peach trees died of cold injury after 4 years of parasitism by $M$. xenoplax, whereas trees in

Received for publication 20 May 2009. Accepted for publication 8 Sept. 2009.

We thank William T. Taylor, Jr., and Morgan A. Sherman for technical assistance.

${ }^{1}$ To whom reprint requests should be addressed; e-mail Andy.Nyczepir@ars.usda.gov. 1990). As a result of the reduced availability of pre- and postplant nematicides in the agricultural market, alternatives to chemical control methods such as rootstock resistance are warranted and are being investigated (Batchelor, 2002).

In the southeastern United States, the peach rootstock Guardian ${ }^{\circledR}$ is recommended over Lovell and other rootstocks previously used by this industry because trees on this rootstock have a higher survival rate on PTSL sites, although $M$. xenoplax reproduces on it
(Nyczepir et al., 1996; Okie et al., 1994a, 1994b). Since 2007, $75 \%$ of peach trees delivered to commercial growers in the southeastern United States have been propagated on Guardian ${ }^{\circledR}$ (M. Watkins, personal communication). Guardian ${ }^{\circledR}$ also has demonstrated resistance to some Meloidogyne spp., but not Pratylenchus vulnus Allen \& Jensen, 1951 (Nyczepir et al., 1999; Nyczepir and Pinochet, 2001) or Armillaria root rot [Armillaria tabescens (Scop.) Dennis, Orton \& Hora] (Beckman et al., 1998).

Armillaria root rot is another leading cause of premature tree death in the southeastern United States (Miller, 1994). The survival of $A$. tabescens on root debris in the soil frequently prevents the establishment of new orchards in previously infested sites and managing Armillaria is extremely difficult once it is established. Rootstock tolerance to Armillaria has been identified in some plum species, which may provide an alternative management tool against this root rot disease (Beckman et al., 1998).

Recently, genetic engineering has been used as a potential means to improve tolerance of plum rootstocks against various rootassociated plant pathogens (Nagel et al., 2008). Developing a Prunus rootstock that is resistant or tolerant to plant-parasitic nematodes is highly desirable. The Gastrodia antifungal protein (GAFP, or Gastrodianin), discovered in the Asiatic orchid (Gastrodia elata), is a monocot mannose-binding lectin with broad spectrum activity against fungal plant pathogens (Wang et al., 2001; Xu et al., 1998). In vitro tests have shown that GAFP inhibits growth of Armillaria mellea (Vahl:Fr.) P. Kumm., suggesting that the protein enhances pathogen defense and protects $G$. elata from A. mellea infection in nature (Hu and Huang, 1994). It was recently demonstrated that expression of the VNF isoform of this lectin ( $g a f p-1-v n f$, hereafter referred to as gafp-1) in transgenic tobacco (Nicotiana tabacum cv. Wisconsin 38) and plum (Prunus domestica lines 4J and 4I) suppressed root galling and reproduction, respectively, of the root-knot nematode, Meloidogyne incognita (Kofoid \& White, 1919) Chitwood, 1949 (Cox et al., 2006; Nagel et al., 2008). Additionally, these transgenic tobacco and plum lines had increased tolerance to Phytophthora nicotianae Breda de Haan and $P$. cinnamomi Rands, respectively. The effect of GAFP-1 in suppressing $A$. tabescens growth or M. xenoplax reproduction is currently unknown. The purpose of this research was to evaluate the susceptibility of the three gafp- 1 expressing plum lines (i.e., 4J, 4I, and 5D) to M. xenoplax.

\section{Materials and Methods}

Transformation of plum. Transgenic plum lines were generated using Agrobacteriummediated transformation of plum hypocotyls from seed of open-pollinated 'Stanley' and the translation of GAFP-1 was confirmed in transgenic lines using immunoblot analysis of root and leaf tissue as described by Nagel 
et al. (2008). Agrobacterium tumefaciensmediated transformation resulted in three gafp-1 expressing plum lines, which were designated $4 \mathrm{I}, 4 \mathrm{~J}$, and 5D. Three transgenic and nontransformed plum lines were evaluated in two greenhouse tests. Plum lines were clonally propagated from the original, transformed, or nontransformed germplasm through softwood cuttings (Nagel et al., 2008).

Host response. The response of transgenic plum lines to the ring nematode, Mesocriconema xenoplax, was evaluated in an airconditioned greenhouse $\left(25 \pm 5{ }^{\circ} \mathrm{C}\right)$ at the USDA-ARS, Southeastern Fruit \& Tree Nut Research Laboratory in Byron, GA. Detailed information on the evaluation technique is according to the method described in Nyczepir et al. (1996). This greenhouse technique proved reliable in the early stages of Guardian ${ }^{\circledR}$ rootstock evaluation.

One hundred eighteen-d-old transgenic plum lines (4I, 4J, and 5D) and a nontransformed plum line (which served as a positive control) along with 110-d-old Nemaguard peach seedlings (ring nematode-susceptible) were transplanted singly into $15-\mathrm{cm}$-diameter plastic pots containing $1500 \mathrm{~cm}^{3}$ steam pasteurized loamy sand ( $86 \%$ sand, $10 \%$ silt, $4 \%$ clay, $0.54 \%$ organic matter; $\mathrm{pH} 6.1$ ). The susceptible peach, Nemaguard, was used to verify ring nematode infectivity. Plants were allowed to acclimate for $2 \mathrm{~d}$ before infesting the soil in each pot with $10 \mathrm{M}$. xenoplax/ $100 \mathrm{~cm}^{3}$ soil. This initial nematode density (Pi) was obtained by scoring in a cross-hatch pattern $(\approx 1 \mathrm{~cm}$ deep) the soil surface in each pot and then pouring a water suspension of 150 M. xenoplax adults or juveniles in $40 \mathrm{~mL}$ water onto the scored area. The nematodes were then washed down into the soil with $\approx 300 \mathrm{~mL}$ water. The ring nematode isolate used was obtained from a peach orchard previously diagnosed as a PTSL site in Byron, GA, and cultured on Nemaguard peach in a shade house. Plants were watered and fertilized as needed and pruned back to a height of $18 \mathrm{~cm}$ above the soil line $90 \mathrm{~d}$ after inoculation to stimulate production of new roots and shoots. All test treatments were harvested $180 \mathrm{~d}$ after inoculation (i.e., 22 Sept. 2005 to 21 Mar. 2006) and the following data were collected: dry root weight (root systems were gently separated from the soil, washed in water, then wrapped in aluminum foil and baked at $70{ }^{\circ} \mathrm{C}$ until no more measurable weight loss) and final nematode soil population density (Pf). Nematodes were extracted from a $100-\mathrm{cm}^{3}$ soil subsample with a semiautomatic elutriator (Byrd et al., 1976) and centrifugal-flotation (Jenkins, 1964) and counted using a stereomicroscope. Host response (resistance/susceptibility) to M. xenoplax was assessed at the end of the experiment by determining 1) the final soil nematode density (Pf) of adult and juvenile nematodes (excluding eggs) per gram of dry root mass; and 2) the ring nematode reproduction factor (Rf) of all motile life stages, which was calculated by dividing the Pf by the initial soil population density (Pi) (i.e., $\mathrm{Rf}=\mathrm{Pf} / \mathrm{Pi})]$ relative to the subsample. Test hosts were grouped into three classifications based on the nematode $\mathrm{Rf}$ rating as follows: nonhost (highly resistant), $\mathrm{Rf}=0$; poor host (resistant), $\mathrm{Rf}=0.01$ to 0.99 ; and good host (susceptible), Rf 1 or greater. The test was repeated once. In the second test, younger (63-d-old) transgenic and a nontransformed plum lines along with 11-d-old Nemaguard peach seedlings were inoculated $6 \mathrm{~d}$ after transplanting and exposed to the nematode infection for $181 \mathrm{~d}$ after inoculation (i.e., 22 May 2008 to 19 Nov. 2008). Inoculation procedures, $\mathrm{Pi}$, seedling handling in the greenhouse, and parameters recorded were the same as those of the previous test.

Nematode data were $\log _{10}(x+1)$ transformed and subjected to analysis of variance with the general linear models procedure of SAS (SAS Institute, Cary, NC). Appropriate preplanned single-degree-of-freedom comparisons were then used to detect differences between treatment means for Nemaguard peach versus combined plum line means following a significant $F$ test. Means within the plum lines were analyzed using Tukey's honestly significant difference test. Actual numerical data were used for table presentation. Only significant differences $(P \leq 0.05)$ are discussed unless stated otherwise.

\section{Results and Discussion}

All plum lines combined supported greater $(P \leq 0.05)$ numbers of $M$. xenoplax than Nemaguard peach (known susceptible) in Test 1. A similar trend occurred in Test 2 although differences were not significant (Table 1). However, when the final nematode population density was expressed on a per gram of dry root basis, no differences were detected between the combined plum lines and Nemaguard in both tests, indicating that all plum lines combined supported similar nematode populations as Nemaguard. Rootstock carrying capacity of nematode infestation levels as measured by number of $M$. xenoplax motile life stages per gram of dry root is a better measure of host resistance/ tolerance than nematodes per $100 \mathrm{~cm}^{3}$ soil, because it standardizes the nematode populations among the different plant species tested based on total root mass . Using this criterion has proven a useful tool in the preliminary identification of tolerance in Guardian ${ }^{\circledR}$ to M. xenoplax (Nyczepir et al., 1996). It was determined that specific Guard$\operatorname{ian}^{\circledR}$ lines suppressed M. xenoplax populations relative to Nemaguard rootstock, but not Lovell. Among the plum lines tested, the number of $M$. xenoplax per gram of dry root was lowest $(P \leq 0.05)$ with transgenic line $5 \mathrm{D}$, intermediate with the nontransformed control line, and greatest with line $4 \mathrm{~J}$ in both tests. In Test 2 , transgenic line $4 \mathrm{I}$ also supported a greater $(P \leq 0.05)$ number of $M$. xenoplax per gram of dry root than line $5 \mathrm{D}$, and in Test 1, a similar trend was detected although differences were not significant. The lower final nematode densities observed on the transgenic plum line 5D reflect a more vigorous and developed root system of this line compared with the other lines tested in this study and also that of Nemaguard peach rootstock. This observation is substantiated in that total dry root weight for transgenic line 5D (Tests 1 and $2=$ 12.11 and $22.51 \mathrm{~g}$, respectively) was greater than transgenic lines 4I (Tests 1 and $2=7.30$ and $7.54 \mathrm{~g}$, respectively) and 4J (Tests 1 and $2=9.69$ and $8.65 \mathrm{~g}$, respectively) and also the nontransformed control line (Tests 1 and $2=8.04$ and $7.48 \mathrm{~g}$, respectively) and Nemaguard peach (Tests 1 and $2=2.11$ and $5.66 \mathrm{~g}$, respectively) (data not presented in Table 1). Plants with large root systems usually support larger nematode populations than plants with reduced root mass.

It is not certain why transgenic line $5 \mathrm{D}$, with a larger root system than the other transgenic lines, supported fewer $M$. xenoplax per gram of dry root, but this specific transgenic line is known to have different genetic and disease performance characteristics than transgenic lines 4I and 4J (Nagel et al., 2008). For example, line 5D has multiple copies of the gafp- 1 insertion (versus $4 \mathrm{~J}=$ one copy and $4 \mathrm{I}=$ two copies). Despite these potential genetic advantages, line 5D is more susceptible to Phytophthora cinnamomi infection than transgenic lines 4I and 4J. Furthermore, transgenic lines $4 \mathrm{~J}, 4 \mathrm{I}$, and 5D were all shown to support lower populations of the Southern root-knot nematode ( $M$. incognita) compared with the inoculated control line, but greatest effects on suppression of root-knot nematode galling and reproduction were observed in transgenic lines 4J and 4I. Two possible explanations for the different response of transgenic line 5D when exposed to the infestation of a species ( $M$. xenoplax) belonging to another nematode genus having different parasitic habits may be attributed to 1) specific feeding sites on the root and nourishment needed to promote reproduction at these sites; and 2) multiple gafp-1 gene copies in this line 5D. Nematode feeding sites on roots differ between a sedentary endoparasite such as the root-knot nematode and a migratory ectoparasite such as the ring nematode. Meloidogyne spp. penetrate at the root tip, become sedentary within the root, and form feeding sites called giant cells within the vascular cylinder region. These endoparasites remain sedentary and feed on established giant cells for the remainder of their life cycle (de Guiran and Ritter, 1979). In contrast, ring nematodes feed from individual cortical cells further back on the root for up to $8 \mathrm{~d}$ and then move to a new feeding site along the root (Hussey et al., 1992), which is modified into discrete food cells. In this study, transgenic line 5D appears to provide less nourishment to M. xenoplax than lines $4 \mathrm{~J}$ and $4 \mathrm{I}$, which is contrary to its effect on M. incognita (Nagel et al., 2008). It is not certain if the GAFP lectin in transgenic plum line 5D suppressed M. xenoplax populations through feeding or direct contact, but like $M$. incognita, M. xenoplax requires specialized feeding cells for sustenance and reproduction. 
Table 1. Population density of Mesocriconema xenoplax on plum (Prunus domestica cv. Stanley) lines and peach cultivars in the greenhouse after 180 d.

\begin{tabular}{|c|c|c|c|c|c|c|c|}
\hline \multirow[b]{3}{*}{ Plant species } & \multirow[b]{3}{*}{ Cultivar/line } & \multicolumn{4}{|c|}{ No. of $M$. xenoplax per } & & \\
\hline & & \multicolumn{2}{|c|}{$100 \mathrm{~cm}^{3}$ soil } & \multicolumn{2}{|c|}{ Gram of dry root } & \multicolumn{2}{|c|}{$\mathrm{Rf}^{\mathrm{z}}$} \\
\hline & & Test $1^{\mathrm{y}}$ & Test $2^{y}$ & Test $1^{\mathrm{y}}$ & Test $2^{y}$ & Test $1^{\mathrm{y}}$ & Test $2^{y}$ \\
\hline Peach & Nemaguard & $4,361^{\mathrm{x}}$ & 20,130 & 2,802 & 4,320 & $436.1^{x}$ & $2,013.0$ \\
\hline \multirow[t]{5}{*}{ Plum } & $4 \mathrm{~J}$ & $20,884 \mathrm{a}^{\mathrm{w}}$ & $30,838 \mathrm{a}^{\mathrm{w}}$ & $3,712 \mathrm{a}^{\mathrm{w}}$ & $5,366 \mathrm{a}^{\mathrm{w}}$ & $2,088.4 \mathrm{a}^{\mathrm{w}}$ & $3,083.8 \mathrm{a}^{\mathrm{w}}$ \\
\hline & $5 \mathrm{D}$ & $9,274 \mathrm{ab}$ & $29,369 \mathrm{a}$ & $909 \mathrm{~b}$ & $1,491 \mathrm{~b}$ & $927.4 \mathrm{ab}$ & $2,936.9 \mathrm{a}$ \\
\hline & $4 \mathrm{I}$ & $8,777 \mathrm{ab}$ & 33,249 a & $1,553 \mathrm{ab}$ & $5,597 \mathrm{a}$ & $877.7 \mathrm{ab}$ & $3,324.9 \mathrm{a}$ \\
\hline & Control & $8,354 \mathrm{~b}$ & $2,287 \mathrm{a}$ & $1,170 \mathrm{ab}$ & $3,571 \mathrm{ab}$ & 835.4 b & $2,287.1 \mathrm{a}$ \\
\hline & Combined plum & 11,822 & 29,082 & 1,836 & 4,006 & $1,182.2$ & $2,908.2$ \\
\hline
\end{tabular}

${ }^{\mathrm{z}} \mathrm{Rf}=$ reproductive factor $(\mathrm{Pf} / \mathrm{Pi})$, where $\mathrm{Pf}=$ final population density of $M$. xenoplax juveniles and adults $/ 100 \mathrm{~cm}{ }^{3}$ soil and $\mathrm{Pi}=$ initial population density of $10 M$. xenoplax juveniles or adults $/ 00 \mathrm{~cm}^{3}$ soil. Rf rating, as follows: nonhost (highly resistant), Rf = 0; poor host (resistant), Rf = 0.01-0.99; and good host (susceptible), Rf 1 or greater.

y Data are means of 10 replicates.

${ }^{\mathrm{x}}$ The single-degree-of-freedom comparison between the means for peach versus combined plum lines was significant $(P \leq 0.05)$.

${ }^{w}$ Means within plum lines and column followed by the same letter are not different $(P \leq 0.05)$ according to Tukey's honestly significant difference test.

Lectins are carbohydrate-binding proteins that have been found in many plants and their properties have been linked to a variety of plant functions, including defense against various plant pathogens (Hu et al., 1988; Koo et al., 2002; Lee et al., 2003; Van Damme et al., 1998; Wang et al., 2001, 2004). It was reported that expression of a monocot mannose-binding lectin (GNA) conferred partial resistance to $M$. incognita in Arabidopsis (Ripoll et al., 2003). The mechanism of plant resistance is not known, but it is believed that GNA may bind glycoproteins on chemoreceptors associated with amphids and (or) the nematode surface. Such disruption would ultimately interfere with nematode sensory discernment and the ability of the nematode to form the essential feeding cells needed for nourishment (Thomas and Cottage, 2006). Furthermore, it was reported that some transgenic Arabidopsis lines were more resistant to $M$. incognita than others and that the most resistant lines did not contain the most copies of the T-DNA insertion region containing the GNA-expression cassette (Ripoll et al., 2003). A similar phenomenon was reported when gafp-l-expressing plum lines were challenged with $M$. incognita (i.e., transformed lines $4 \mathrm{~J}$ and $4 \mathrm{I}$, but not line $5 \mathrm{D}$ ) (Nagel et al., 2008). In contrast, transgenic plum lines $4 \mathrm{~J}$ (one gafp-1 gene copy) and 4I (two gafp-1 gene copies) supported greater M. xenoplax populations than line 5D (four gafp-1 gene copies) when compared on a per gram of dry root basis. It appears that increased copy number or transcript expression levels may be correlated with suppression of $M$. xenoplax populations, but not $M$. incognita.

All plum lines tested in this study were rated as susceptible hosts ( $\mathrm{Rf} 1$ or greater) to M. xenoplax (Table 1). Differences between the combined plum lines and Nemaguard and among the individual plum lines were variable. In previous greenhouse trials, there have been no reports to date of a Prunus selection that supported little or no population increase by $M$. xenoplax (i.e., $\mathrm{Rf}=0$ to $1.0)$; this includes Guardian ${ }^{\circledR}$ peach rootstock and a number of plum cultivars such as 'Myrobalan' plum (Nyczepir et al., 1996; Seshadri, 1964; Westcott et al., 1994). The results reported here substantiate that plum is a host to M. xenoplax. However, differences among transgenic lines are present in the current study with the number of M. xenoplax per gram of dry root being lowest with transgenic line 5D.

Host susceptibility of line 5D to root-knot nematode versus $M$. xenoplax is intriguing, because similar host reactions have been reported for some commercial peach rootstocks. For example, Lovell (root-knot nematodesusceptible, $M$. xenoplax-susceptible) is known to survive longer on PTSL sites than Nemaguard (root-knot nematode-resistant, M. xenoplax-susceptible). Although the transgenic line 5D was determined to be a susceptible host to $M$. xenoplax based on $\mathrm{Rf} 1$ or greater, additional field testing of this line in an orchard having a history of PTSL and (or) infested with Armillaria root $\operatorname{rot}(A$. tabescens) would be of interest to determine if tree survival is prolonged or otherwise altered.

\section{Literature Cited}

Batchelor, T.A. 2002. International and European community controls on methyl bromide \& the status of methyl bromide use and alternatives in the European Community, p. 28-32. In: Batchelor, T.A. and J.M. Bolivar (eds.). Proc. Intl Conf. Alter. Methyl Bromide "The remaining challenges." European Commission, Brussels, Belgium.

Beckman, T.G., W.R. Okie, A.P. Nyczepir, P.L. Pusey, and C.C. Reilly. 1998. Relative susceptibility of peach and plum germplasm to Armillaria root rot. HortScience 33:1062-1065.

Brittain, J.A. and R.W. Miller. 1978. Managing peach tree short life in the Southeast. Clemson Univ. Ext. Serv. Bul. 585.

Byrd, D.W., Jr., K.R. Barker, H. Ferris, C.J. Nusbaum, W.E. Griffin, R.H. Small, and C.A. Stone. 1976. Two semi-automatic elutriators for extracting nematodes and certain fungi from soil. J. Nematol. 8:206-212.

Clean Air Act. 1990. Title VI. Stratospheric Ozone Protection, S.1630, Public Law No. 101-549, Section 602. U.S. Congress, Washington, DC.

Cox, K.D., D.R. Layne, R. Scorza, and G. Schnabel. 2006. Gastrodia anti-fungal protein from the orchid Gastrodia elata confers disease resistance to root pathogens in transgenic tobacco. Planta 224:1373-1383.

de Guiran, G. and M. Ritter. 1979. Life cycle of Meloidogyne species and factors influencing their development, p. 173-191. In: Lamberti, F. and C.E. Taylor (eds.). Root-knot nematodes
(Meloidogyne species): Systemics, biology, and control. Academic Press, New York, NY.

Horton, D., P. Brannen, B. Bellinger, and D. Ritchie. 2009. 2009 Southeastern peach, nectarine, and plum pest management and culture guide. Univ. of Georgia Coop. Ext. Serv. Bul. $\# 1171$.

Hu, Z. and Q.Z. Huang. 1994. Induction and accumulation of the antifungal protein in Gastrodia elata. Acta Bot. Yunnan. 16:169-177.

Hu, Z., Z. Yang, and J. Wang. 1988. Isolation and partial characterization of an antifungal protein from Gastrodia elata corm. Acta Bot. Yunnan. 10:373-380.

Hussey, R.S., C.W. Mims, and S.W. Westcott, III. 1992. Ultrastructure of root cortical cells parasitized by the ring nematode, Criconemella xenoplax. Protoplasma 167:55-65.

Jenkins, W.R. 1964. A rapid centrifugal-flotation technique for separating nematodes from soil. Plant Dis. Rptr. 48:692.

Koo, J.C., H.J. Chun, H.C. Park, M.C. Kim, Y.D. Koo, S.C. Koo, H.M. Ok, S.J. Park, S.H. Lee, D.J. Yun, C.O. Lim, J.D. Bahk, S.Y. Lee, and M.J. Cho. 2002. Over-expression of a seed specific hevein-like antimicrobial peptide from Pharbitis nil enhances resistance to a fungal pathogen in transgenic tobacco plants. Plant Mol. Biol. 50:441-452.

Lee, O.K., B. Lee, N. Park, J.C. Koo, Y.H. Kim, T.P. Da, C. Karigar, H.J. Chun, B.R. Jeonga, D.H. Kim, J. Nam, J.G. Yun, S.S. Kwak, M.J. Cho, and D.J. Yun. 2003. Pn-AMPs, the hevein-like proteins from Pharbitis nil confers disease resistance against phytopathogenic fungi in tomato, Lycopersicum esculentum. Phytochemistry 62:1073-1079.

Lownsbery, B.F., H. English, E.H. Moody, and F.J. Schick. 1973. Criconemoides xenoplax experimentally associated with a disease of peach trees. Phytopathology 63:994-997.

Miller, R.W. 1994. Estimated peach tree losses 1980 to 1992 in South Carolina: Causes and economic impact, p. 121-127. In: Nyczepir, A.P., P.F. Bertrand, and T.G. Beckman (eds.). Proc. 6th Stone Fruit Decline Workshop, 26-28 Oct. 1992, Ft. Valley, GA.

Nagel, A.K., G. Schnabel, C. Petri, and R. Scorza. 2008. Generation and characterization of transgenic plum lines expressing the Gastrodia antifungal protein. HortScience 43:1514-1521.

Nyczepir, A.P., T.G. Beckman, and G.L. Reighard. 1999. Reproduction and development of Meloidogyne incognita and M. javanica on Guardian peach rootstock. J. Nematol. 31:334-340.

Nyczepir, A.P., W.R. Okie, and T.G. Beckman. 1996. Evaluating Prunus genotypes for resistance/ tolerance to Criconemella xenoplax, p. 3742. In: Halbrendt, J.M., G.L. Reighard, and 
A.P. Nyczepir (eds.). Proc. 5th Stone Fruit Decline Workshop, 24-26 Sept. 1990, Biglerville, PA.

Nyczepir, A.P., W.R. Okie, and T.G. Beckman. 2004. Creating a short life site for Prunus rootstock evaluation on land with no innate Mesocriconema xenoplax population. HortScience 39:124-126.

Nyczepir, A.P. and J. Pinochet. 2001. Assessment of Guardian peach rootstock for resistance to two isolates of Pratylenchus vulnus. J. Nematol. 33(suppl):302-305.

Nyczepir, A.P., C.C. Reilly, and W.R. Okie. 1987. Effect of initial population density of Criconemella xenoplax on reducing sugars, free amino acids, and survival of peach seedlings over time. J. Nematol. 19:296-303.

Nyczepir, A.P., E.I. Zehr, S.A. Lewis, and D.C. Harshman. 1983. Short life of peach trees induced by Criconemella xenoplax. Plant Dis. 67:507-508.

Okie, W.R., T.G. Beckman, A.P. Nyczepir, G.L. Reighard, W.C. Newall, Jr., and E.I. Zehr. 1994a. BY520-9, a peach rootstock for the southeastern United States that increases scion longevity. HortScience 29:705-706.
Okie, W.R., G.L. Reighard, T.G. Beckman, A.P. Nyczepir, C.C. Reilly, E.I. Zehr, and W.C. Newall, Jr. 1994b. Field-screening Prunus for longevity in the southeastern United States. HortScience 29:673-677.

Ripoll, C., B. Favery, P. Lecomte, E. Van Damme, W. Peumans, P. Abad, and L. Jouanin. 2003. Evaluation of the ability of lectin from snowdrop (Galanthus nivalis) to protect plants against root-knot nematodes. Plant Sci. 164:517-523.

Savage, E.F. and F.F. Cowart. 1942. Factors affecting peach tree longevity in Georgia. Georgia Agr. Expt. Sta. Res. Bul. 219.

Seshadri, A.R. 1964. Investigations on the biology and life cycle of Criconemoides xenoplax Raski, 1952 (Nematoda: Criconematidae). Nematologica 10:540-562.

Thomas, C. and A. Cottage. 2006. Genetic engineering for resistance, p. 255-272. In: Perry, R.N. and M. Moens (eds.). Plant nematology. CABI, Wallingford, UK.

Van Damme, E.J.M., W.J. Peumans, A. Barre, and P. Rouge. 1998. Plant lectins: A composite of several distinct families of structurally and evolutionary related proteins with diverse biological roles. Crit. Rev. Plant Sci. 17:575692.

Wang, X., G. Bauw, E.J.M. Van Damme, W.J. Peumans, Z.-L. Chen, M. Van Montagu, G. Angenon, and W. Dillen. 2001. Gastrodianinlike mannose-binding proteins: A novel class of plant proteins with antifungal properties. Plant J. 25:651-661.

Wang, Y., D. Chen, D. Wang, Q. Huang, Z. Yao, F. Liu, X. Wei, R. Li, Z. Zhang, and Y. Sunday. 2004. Over-expression of Gastrodia antifungal protein enhances Verticillium wilt resistance in coloured cotton. Plant Breed. 23: 454-459.

Westcott, S.W. III, E.I. Zehr, W.C. Newall, Jr., and D.W. Cain. 1994. Suitability of Prunus selections as hosts for the ring nematode (Criconemella xenoplax). J. Amer. Soc. Hort. Sci. 119: 920-924.

Xu, Q., Y. Liu, X. Wang, H. Gu, and Z. Chen. 1998. Purification and characterization of a novel anti-fungal protein from Gastrodia elata. Plant Physiol. Biochem. 36:899-905. 